\title{
The Role of Ovarian Surface Epithelium in Folliculogenesis during Fetal Development of the Bovine Ovary: A Histological and Immunohistochemical Study
}

\author{
R.A.-M. Kenngott M. Vermehren K. Ebach F. Sinowatz \\ Department of Veterinary Sciences, Institute for Anatomy, Histology, and Embryology, \\ Ludwig-Maximilians-University, Munich, Germany
}

\section{Key Words}

Bovine - Development · Ovary · Surface epithelium

\begin{abstract}
Although many aspects of ovarian differentiation have been established, comparatively little is known about prenatal follicle formation and differentiation of bovine ovaries. The objective of this investigation was to study the role of the surface epithelium during the development of germ cell nests, germ cell cords and follicle formation in the fetal bovine ovary. Associated important proliferation and apoptotic features were further investigated. Additionally, the expression pattern of the $\mathrm{S} 100$ protein was detected. A strong increase of mitotic figures was detected in the surface epithelium, germ cell nests and germ cell cords of ovaries with a crownrump length (CRL) of 13.0-58.0 cm. Oocytes were positively stained with $\mathrm{S} 100$ in bovine ovaries from fetuses with a CRL of $21.0 \mathrm{~cm}$. The staining intensity enhanced parallel to increasing oocyte and follicle sizes during the ovary development. In later stages, a strong staining for $\mathrm{S} 100$ was observed in healthy oocytes in contradistinction to atretic oocytes where no expression of the $\mathrm{S} 100$ protein could be found. In conclusion, increasing mitosis index of surface epithelium cells, as well as oogonia directly beneath the surface epithe-
\end{abstract}

(c) 2013 S. Karger AG, Basel

$1661-5425 / 13 / 0074-0180 \$ 38.00 / 0$ lium, in combination with open surface connection during stages from a CRL of $11.0-94.0 \mathrm{~cm}$ of bovine fetal ovaries could play an important role in the period of time of ongoing folliculogenesis and derivation of granulosa cells. Additionally, S100-positive oocytes in primordial and later follicle stages joined by a high rate of Ki67-positive index in surrounding granulosa cells indicate that in the oocytes the S100 protein can perhaps be a useful marker for intact oocytes in bovine ovaries.

Copyright $\odot 2013$ S. Karger AG, Basel

Normal fetal development of the ovary is essential for fertility and reproductive success during adult life [Sarraj and Drummond, 2012]. Therefore, healthy pre-antral follicular dynamics depending on normal concentrations of a great number of hormones and local factors, which influence primordial follicular activation and subsequent follicular development, are important [Aerts and Bols, 2010]. The mammalian ovaries contain a large number of nongrowing primordial follicles [Aerts and Bols, 2010]. In contrast to rodents and rabbits, where primordial follicles form only shortly after birth, the pool of primordial follicles of primates and most domestic animals establish already during fetal development [Fortune, 2003]. Ab-

\section{KARGER}

E-Mail karger@karger.com

www.karger.com/sxd
Rebecca Anna-Maria Kenngott

Department of Veterinary Sciences, Institute for Anatomy, Histology, and Embryology Ludwig-Maximilians-University, Veterinärstrasse 13 DE-80539 Munich (Germany)

E-Mail r.kenngott@anat.vetmed.uni-muenchen.de 
normalities during prenatal development of the bovine ovary can result in a restricted number of healthy primordial follicles leading to a reduced fertility during adult life. Ireland et al. [2007] reported that cattle with a larger quantity of healthy follicles in their ovaries produce a correspondingly higher number of transferable embryos. In addition, the quantity of in vitro fertilized oocytes that evolves into blastocysts increases 4 -fold in these animals.

Prenatal ovarian development has been studied in several mammalian species, including the bovine [Jost et al., 1973; Pelliniemi and Salonius, 1976; Rüsse and Sinowatz, 1998; Wrobel and Suss, 1998; Edson et al., 2009]. There are species-specific differences, especially in timing of folliculogenesis, but important steps of ovarian development, such as migration of primordial germ cells (PGCs) into the genital ridge and their proliferation, formation of ovigerous cords and also the generation of follicles appear to be similar in most mammalian species [Mauleon, 1969; Rüsse and Sinowatz, 1998].

The development of the urogenital system is closely linked to the mesonephros. Both components derive from the nonsegmented intermediate mesoderm. Two duct systems develop in the mesonephros, the mesonephric duct (Wolffian duct) and the Müllerian duct, the anlage of the oviduct, uterus and parts of the vagina [Baumgartner, 1910; Grünwald, 1941; Didier, 1973; Viebahn et al., 1987; Kenngott and Sinowatz, 2007]. On the ventromedial side of the bovine mesonephros, the first indifferent gonad primordium called genital ridge or genital crest can be discerned at day 28-32 of gestation [Fischel, 1929; Clara, 1965; Noden and de Lahunta, 1985; Rüsse and Sinowatz, 1998]. The genital ridge consisting of coelomic epithelium and an aggregation of underlying mesenchymal cells starts to proliferate with the arrival of the PGCs [Byskov, 1986; Pereda et al., 2006]. During this indifferent stage of gonadal development the PGCs migrate from the yolk sac via hindgut wall and dorsal mesentery into the genital ridge [McGee et al., 1998; Rüsse and Sinowatz, 1998]. Chemotactic factors probably stimulate the amoeboid migration of the PGCs [Picton et al., 1998]. In bovine fetuses, PGC migration normally takes place between day 30 and 64 of gestation [Rüsse and Sinowatz, 1998].

The differentiation of the female gonad occurs somewhat delayed compared to the male gonad. A specific characteristic of ovary development is the marked formation of the ovarian cortex and the nearly complete lacking of a tunica albuginea [Jost et al., 1973]. During migration, PGCs divide mitotically and differentiate into oogonia at the arrival in the fetal ovary. Investigations of fetal rat ovary show that initial proliferation of mitotic oogonia is nonclonal in contrast to clonal terminal mitosis [Wartenberg et al., 1998]. It is assumed that in the fetal bovine ovary, 2 cells with different functions originate from one primordial germ cell. One cell remains in periphery of the gonad, a stem cell for new generations of oogonia, the second primordial germ cell differentiates into oogonia and initiates oogonia nest generation [Rüsse,1983; Rüsse and Sinowatz, 1998]. After reaching the developing gonad, somatic cells surrounded germ cells. They are integrated in sex cords [Smitz and Cortvrindt, 2002]. Mitosis of oogonia within the germ cell nests appears to occur synchronously, and after division, intercellular bridges always join the divided oogonia [Motta et al., 1997; Juengel et al., 2002] After several mitotic divisions, oogonia enter the first meiotic division prophase and are arrested in the diplotene stage, now being called primary oocytes [Aerts and Bols, 2010] In human [Fulton et al., 2005] and sheep [Juengel et al., 2002], proliferation of oogonia and meiosis of oocytes occur at the same time during the later developing stages of the ovary. There are several different hypotheses about the derivation of the somatic cells of the follicles, the so-called pregranulosa cells. One opinion is that pregranulosa cells derive from the fetal ovary surface epithelium [Gondos, 1975]. Other authors postulate that these cells originate from the ovarian interstitial cells [Hirshfield, 1992] or the rete ovarii [Byskov and LinternMoore, 1973; Byskov, 1975]. First appearance of cattle primordial follicles is observed between 90 and 140 days post coitum (p.c.) [Yang and Fortune, 2008]. In cattle, the peak number of germ cells during fetal life is about $2,100,000$. This number is reduced to an average of 130,000 germ cells at birth [Erickson, 1966a, b; Aerts and Bols, 2010], mostly a result of apoptosis. In the mouse, two-thirds of the follicular germ cells nests undergo apoptosis during day 1-5 of postnatal life. Loss of intercellular bridges and breakdown of germ cell nests occur concomitantly [Pepling and Spradling, 1998] In sheep, apoptosis of germ cells is described during the prenatal ovarian development, but no distinct point in time is specified [Juengel et al., 2002].

This paper focuses on the role of proliferation and apoptosis found in PGCs/oogonia during bovine prenatal ovarian development. The role of the ovarian surface epithelium cells for follicle development is carefully investigated. The immunohistochemical studies also reveal that the expression of the $\mathrm{S} 100$ protein can be used as a marker for healthy germ cells. 
Table 1. Overview of the used antibodies

\begin{tabular}{|c|c|c|c|c|c|}
\hline $\begin{array}{l}\text { Primary antibody dilution, } \\
\text { incubation time, incubation } \\
\text { temperature }\end{array}$ & Clonality, animal species & $\begin{array}{l}\text { Distributor of the } \\
\text { primary antibody }\end{array}$ & $\begin{array}{l}\text { Secondary antibody dilution, } \\
\text { incubation time, incubation } \\
\text { temperature }\end{array}$ & Positive control & $\begin{array}{l}\text { Accession } \\
\text { numbers }\end{array}$ \\
\hline S100 & $\begin{array}{l}\text { polyclonal, } 1: 500,20 \mathrm{~h}, 4^{\circ} \mathrm{C} \text {, } \\
\text { rabbit }\end{array}$ & $\begin{array}{l}\text { Dako, Heidelberg, } \\
\text { Germany }\end{array}$ & anti-rabbit, 1:400, $30 \mathrm{~min}, \mathrm{rt}$ & bovine brain & ZO311 \\
\hline Ki67 & $\begin{array}{l}\text { monoclonal, } 1: 50,20 \mathrm{~h}, 4^{\circ} \mathrm{C} \text {, } \\
\text { mouse }\end{array}$ & Dako & $\begin{array}{l}\text { VECTASTAIN }{ }^{\circledR} \text { Elite }{ }^{\circledR} \\
\text { ABC KIT (PK6200; Vector, } \\
\text { Burlingham) }\end{array}$ & duodenum & M7240 \\
\hline
\end{tabular}

\section{Material and Methods}

\section{Tissue Samples and Preparation}

Tissue samples from bovine fetal ovaries were procured from the local Munich slaughterhouse. Bovine fetuses of indifferent period of sexual development (ranging from $0.9-2.5 \mathrm{~cm}$ crown-rump length (CRL)), female bovine fetuses (ranging from $3.0-7.4 \mathrm{~cm}$ CRL) as well as fetal ovaries of different development stages (table $2 \mathrm{a}, \mathrm{b}$ ) were investigated in this study (all methods of embryo and fetus collecting and cutting according to earlier publications [Kenngott and Sinowatz, 2007, 2008]). All fetuses and ovaries used in this investigation appeared morphologically normal. Gestation age was calculated from the CRL using the tables of Rüsse and Sinowatz [1998].The ovaries of the fetuses were dissected free from the surrounding tissue within $10 \mathrm{~min}$ after slaughter. The fetal sex of the indifferent stages was determined by the presence or absence of the SRY gene. Therefore, genomic DNA was extracted from somatic tissue of each indifferent embryo using QIAamp DNA Micro Kit (Qiagen) with a predicted amplicon size of 109 bp. Specific primers were designed based on the bovine $S R Y$ gene mRNA sequence (Gen-Bank Accession NM_001014385.1). Gene expression was measured using the Amplification CFX96 Real-Time PCR System (Bio-Rad Laboratories Inc., Hercules, Calif., USA). The amplicons were then checked by running them in a $1.5 \%$ GelRed (Biotoim Inc., Hayward, Calif., USA) stained agarose gel. Single band (109) indicated the tissue sample coming from a male bovine embryo, whereas no band declared that the sample descended from a female embryo.

Fetuses smaller than $2.5 \mathrm{~cm}$ were fixed in toto in Bouin's solution (picric acid 1,500 ml, glacial acetic acid $500 \mathrm{ml}, 37 \%$ formalin $100 \mathrm{ml}$ ) or $3.7 \%$ phosphate-buffered paraformaldehyde for $12 \mathrm{~h}$. Fetuses larger than $2.5 \mathrm{~cm}$ were cut into 2 parts at the level of the cubical joint. From the caudal half of the body, gastrointestinal tract, liver and limbs were deleted and the remaining specimen was fixed in Bouin's solution or 3.7\% phosphate-buffered paraformaldehyde for $48 \mathrm{~h}$. From fetuses larger than $10.0 \mathrm{~cm} \mathrm{CRL}$, the ovaries were also dissected and fixed in Bouin's solution or 3.7\% phosphate-buffered paraformaldehyde for $48 \mathrm{~h}$ (methods of embryo and fetus collecting and cutting were accorded to earlier publications [Kenngott and Sinowatz, 2007, 2008]). After fixation each tissue sample was dehydrated in a graded series of alcohols and embedded in paraffin. Serial sections ( $5 \mu \mathrm{m}$ thick) were cut with a Leitz microtome Typ1516 (Firma Leitz GmbH, Wetzlar, Germa- ny). Sections of all stages were stained with haematoxylin-eosin (HE) and Goldner according to the methods of Romeis and Böck [1989]. Tissue preparation for light microscopy and immunohistochemistry were according to the methods of Mulisch and Welsch [2010] and were described already in earlier publications [Kenngott and Sinowatz, 2007, 2008; Kenngott et al. 2011].

\section{Immunohistochemistry}

For immunohistochemical studies $5 \mu \mathrm{m}$ serial sections were collected on slides (SupraFrost Ultra Plus, Menzel-Gläser) coated with APES (aminopropyltriethoxysilane). For antigen retrieval, sections were incubated with proteinase XXIV 0.1\% (Sigma, $\mathrm{P} 8038$ ) for $15 \mathrm{~min}$ and washed with $\mathrm{PBS}$ buffer $\mathrm{pH}$ 7.4. Endogenous peroxidase activity was blocked with $0.1 \% \mathrm{H}_{2} \mathrm{O}_{2}$ at room temperature for $10 \mathrm{~min}$. A preincubation with Dako Protein-BlockSerum-Free was applied for $20 \mathrm{~min}$ to reduce nonspecific antibodies binding and sections were subsequently washed $3 \times$ in PBS $(3 \times$ $5 \mathrm{~min})$. Incubation was performed in a humid chamber at a temperature of $4^{\circ} \mathrm{C}$ using the $\mathrm{ABC}$ technique of Noll and SchaubKuhnen [2000]. The primary polyclonal and monoclonal antibodies used in this study are listed in table 1 . After incubation with the secondary antibody, the slides were washed $3 \times$ with PBS $(3 \times$ $5 \mathrm{~min}$ ) followed by a development with $\mathrm{DAB}$ (diaminobenzidine) for 5-10 min. To stop the reaction, sections were then washed in distilled water. Hereafter, the slides were slightly stained in haematoxylin $(30 \mathrm{sec}$ ). For negative controls, buffer (Dako) replaced the specific primary antibody. As positive controls, we used tissues with known specific immunostaining reactions (table 1) to the antibodies used in this study.

\section{Terminal Transferase-Mediated Nick-End Labeling Method}

The terminal transferase-mediated nick-end labeling method was used for demonstration of apoptotic cells according to the manufacturer's protocol for the Apoptosis detection Kit S7100 (Chemicon).

For quantification of mitotic cells in the investigated ovaries, mitotic PGCs/oogonia/pregranulosa cells were counted in 5 high magnification fields (objective: $40 \times$, Leitz Diaplan, Leica, Germany) of 5 sections from each fetus. The results of mitosis were evaluated with a one-way analysis of variance (ANOVA). A significant difference was assumed at a $\mathrm{p}$ value $<0.05$. 
Table 2a. Overview of important steps during development and differentiation of the bovine ovaries

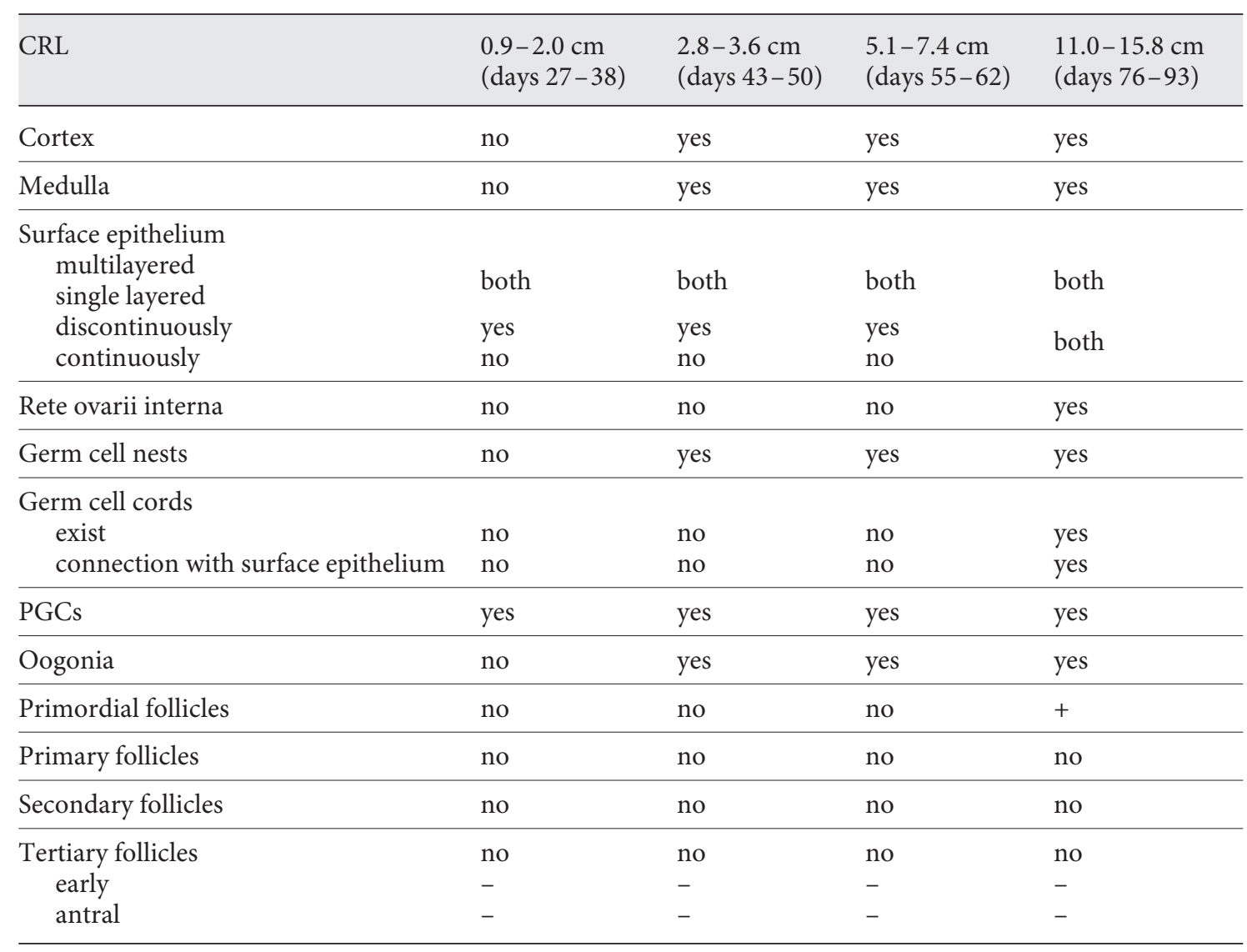

\section{Results}

Morphology and Histology of Developing Fetal Bovine Ovaries

Gonads Obtained from Bovine Embryos and Fetuses with CRLs of $0.9-2.0 \mathrm{~cm}$ CRL (27-38 days p.c.)

The prominent mesonephros and genital ridge in bovine fetuses can be identified at a CRL of $0.9 \mathrm{~cm}$. Table 2 a, b shows an overview of important steps during development and differentiation of the fetal ovaries. The mesonephros consists of many glomerula, and giant glomerula are regularly detected (fig. 1A). An epithelium thickening on the ventromedial side of the mesonephros marks the gonadal ridge in these CRL. Mesonephros surface epithelium is single layered, with exception of gonadal thickening, prismatic and well differentiated. Epithelium cells cytoplasm in this region is slightly eosinophilic with a centrally located nucleus. Epithelium is separated from the underlying mesenchyme by a distinct basal lamina, very clearly immunostained by anti-laminin antibody. Gonadal ridge epithelium is now composed of single or double layered epithelium cells. The surface epithelium cells of the gonadal ridge show a dark eosinophilic cytoplasm as well as mostly round to oval shaped nuclei with a prominent nucleolus. The laminin positive gonadal ridge basal lamina appears incomplete. In bovine fetuses with CRL $1.8-2.0 \mathrm{~cm}$, the mesenchymal cells and the coelomic epithelium of the genital ridge proliferate, and the undifferentiated gonadal primordium is more elongated. The gonad consists of loosely arranged mesenchymal cells with no definite organization. Cords of proliferated surface epithelium cells penetrate the basal lamina and intrude into the gonadal mesenchyme. Surface epithelium is multilayered, but in several regions, the epithelium cells lose their polarity. Large round to oval PGCs with central nuclei, 1 or 2 prominent nucleoli and only slightly stained cytoplasm can be found between the proliferated surface epithelium cells. The 
Table 2b. Overview of important steps during development and differentiation of the bovine ovaries

\begin{tabular}{|c|c|c|c|c|}
\hline CRL & $\begin{array}{l}21.0-34.0 \mathrm{~cm} \\
(\text { days } 95-150)\end{array}$ & $\begin{array}{l}44.8-58.0 \mathrm{~cm} \\
(\text { days } 160-196)\end{array}$ & $\begin{array}{l}66.0-74.0 \mathrm{~cm} \\
(\text { days } 200-230)\end{array}$ & $\begin{array}{l}90.0-94.0 \mathrm{~cm} \\
\text { (days } 240-285 \text { ) }\end{array}$ \\
\hline Cortex & yes & yes & yes & yes \\
\hline Medulla & yes & yes & yes & yes \\
\hline $\begin{array}{l}\text { Surface epithelium } \\
\text { multilayered } \\
\text { single layered } \\
\text { discontinuously } \\
\text { continuously }\end{array}$ & $\begin{array}{l}\text { both } \\
\text { yes } \\
\text { sporadic }\end{array}$ & $\begin{array}{l}\text { reduced } \\
\text { yes } \\
\text { both }\end{array}$ & $\begin{array}{l}\text { reduced } \\
\text { yes } \\
\text { sporadic } \\
\text { mostly }\end{array}$ & $\begin{array}{l}\text { sporadic } \\
\text { mostly } \\
\text { sporadic } \\
\text { mostly }\end{array}$ \\
\hline Rete ovarii & mostly & yes & yes & yes \\
\hline Germ cell masses & yes & yes & sporadic & no \\
\hline $\begin{array}{l}\text { Germ cell cords } \\
\text { exist } \\
\text { connection with surface epithelium }\end{array}$ & $\begin{array}{l}\text { yes } \\
\text { yes }\end{array}$ & $\begin{array}{l}\text { yes } \\
\text { yes }\end{array}$ & $\begin{array}{l}\text { sporadic } \\
\text { sporadic }\end{array}$ & $\begin{array}{l}\text { sporadic } \\
\text { sporadic }\end{array}$ \\
\hline PGCs & yes & yes & yes & sporadic \\
\hline Oogonia & yes & yes & few & sporadic \\
\hline Primordial follicles & ++ & +++ & +++ & +++ \\
\hline Primary follicles & + & ++ & +++ & +++ \\
\hline Secondary follicles & no & + & ++ & ++ \\
\hline $\begin{array}{l}\text { Tertiary follicles } \\
\text { early } \\
\text { antral }\end{array}$ & $\begin{array}{l}\text { no } \\
- \\
-\end{array}$ & $\begin{array}{l}\text { yes } \\
+ \\
-\end{array}$ & $\begin{array}{l}\text { yes } \\
+ \\
-\end{array}$ & $\begin{array}{l}\text { yes } \\
++ \\
++\end{array}$ \\
\hline
\end{tabular}

PGCs are often detected in discontinuous basal lamina areas. At this point of development, the gonad is still indifferent. Male and female gonads cannot be discerned morphologically.

Ovaries Obtained from Bovine Fetuses with a CRL of $2.8-3.6 \mathrm{~cm}$ (43-50 days p.c.)

Female and male bovine gonads in these developing stages can be distinguished by means of light microscopy through absence of the tunica albuginea in the female gonad. The genital ridge appears thickened in the middle part, which later forms the fetal ovary projecting into the coelomic cavity. The ovary is attached to the mesonephros by a mesovarium. The giant glomerulum is in broad connection with the emerging ovary. Cranial and caudal genital fold parts develop into the ligaments of the female gonad. At this developmental stage, the early ovary consists of a dense, broad, peripheral region adjacent to the coelomic epithelium and a less dense central zone (fig. 1B). Glomerula and tubuli of the mesonephros can be observed in the central area. Therefore, this central area consists of a loose arrangement of polygonal cells with a light cytoplasm. The nuclei of these cells are often elongated and small with 2-3 nucleoli. Distinct intercellular spaces can be observed between the medulla mesenchymal cells, in contrast to the more densely arranged somatic cells of the peripheral cortex region. Many PGCs have colonized the ovary surface epithelium, showing strong mitotic activity. All stages of mitosis can be observed in the PGCs and the surface epithelial cells. The fetal bovine ovaries surface epithelium cells are thin and columnar-shaped with either a vertical orientation or irregularly arranged in the proliferated, multilayered areas. Nuclei of the epithelial cells are oval and centrally located in the cytoplasm. Surface epithelium shows some areas with a multilayered epithelium, especially where 


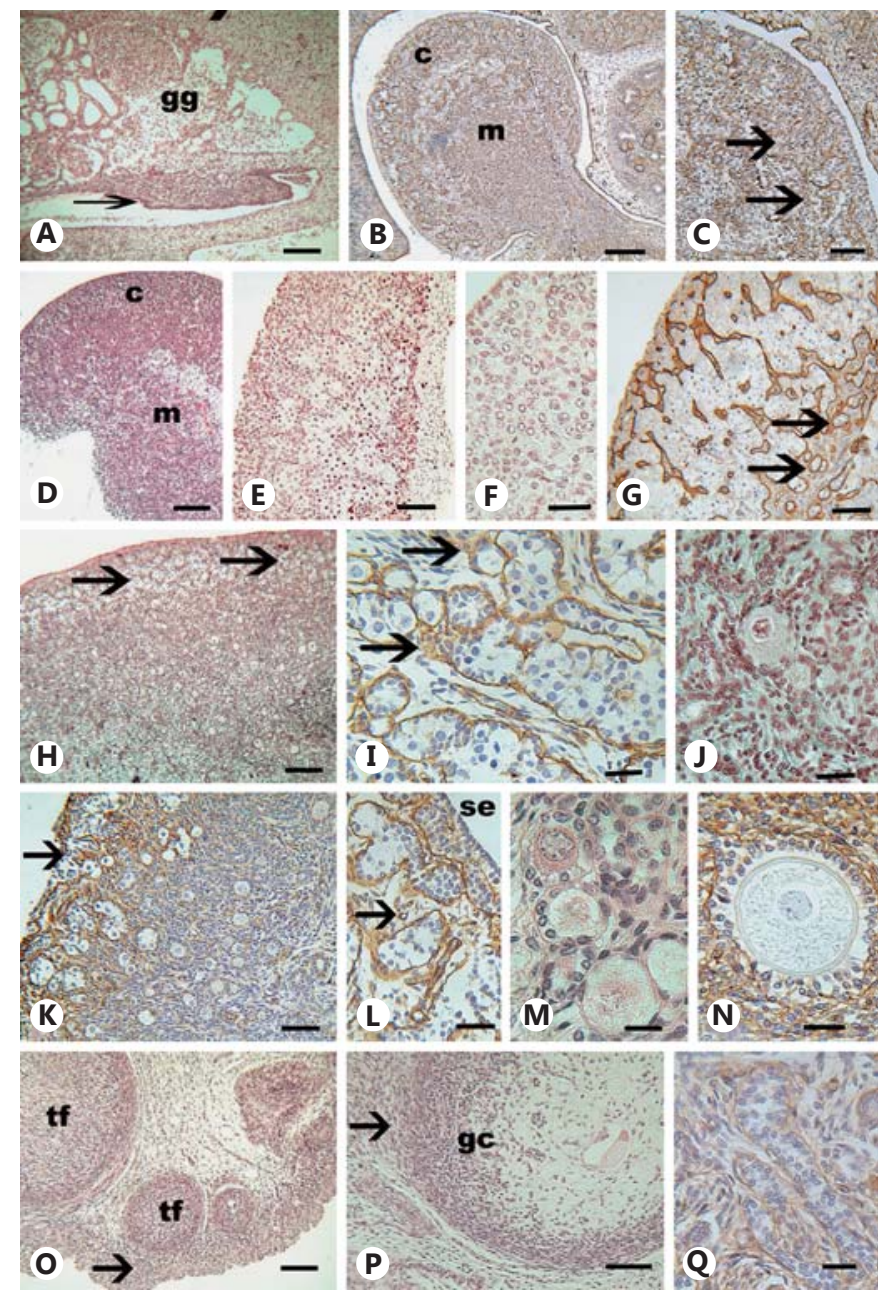

Fig. 1. Representative serial sections of different fetal ovaries (stained with hematoxylin and eosin (HE), Goldner or incubated with the antibody against laminin) show the morphology of important features during the developing stages of the fetal bovine ovary. A Longitudinal section through the mesonephros of bovine fetus with CRL of $0.9 \mathrm{~cm}$. On the ventromedial side of the mesonephros a gonadal thickening (arrow) can be observed. gg = Giant glomerulum. Scale bar $(\mathrm{sb})=400 \mu \mathrm{m}$. B Longitudinal section through the mesonephros of bovine fetus with CRL of $2.8 \mathrm{~cm}$. The female gonad can be identified by the absence of the tunica albuginea. The ovary consists of a dense broad region (c) and a less dense central zone (m). Antibody against laminin, $\mathrm{sb}=100 \mu \mathrm{m}$. C Bovine developing ovary of a fetus with CRL $3.6 \mathrm{~cm}$. Note the multilayered surface epithelium and the open connection to the germ cell nests, which are enveloped in a basal lamina (arrows), $s b=100 \mu \mathrm{m}$. D Longitudinal section through the ovary of fetus with CRL $11.4 \mathrm{~cm}$. Note the cortex (c) which encloses developing germ cells cords. Also, note the medulla (m) with many blood vessels. Staining HE, $\mathrm{sb}=200 \mu \mathrm{m}$. E Longitudinal section through the ovary of fetus with CRL $11.4 \mathrm{~cm}$. On the inner side of the cortex, note the meiotic oocytes within the end of the germ cell cords. Staining HE, $s b=100 \mu \mathrm{m}$. F Longitudinal section through the ovary of fetus with CRL $15.8 \mathrm{~cm}$. Note the large round oogonia, which are often in mitosis. Staining $\mathrm{HE}, \mathrm{sb}=$ $50 \mu \mathrm{m}$. G Longitudinal section through the ovary of fetus with CRL $15.8 \mathrm{~cm}$. On the end of the germ cell cords lying near the medulla region single groups of oocytes and pregranulosa cells are separated by basal lamina. The prominent basal lamina encloses the germ cell cords and the groups of oocytes and pregranulosa cells near the medulla (arrows). Antibody against laminin, $s b=80 \mu \mathrm{m}$. H Fetal ovary of CRL $21.0 \mathrm{~cm}$. In the outer cortex, many germ cell nests generating germ cell cords can be observed (arrows). Staining HE, $\mathrm{sb}=100 \mu \mathrm{m}$. I Detail of the inner cortex of fetal ovary with CRL 28.0 $\mathrm{cm}$. Note the generation of new follicles on the end of the germ cell cords (arrows). Antibody against laminin, $s b=50 \mu \mathrm{m}$. J Detail of the inner cortex of fetal ovary with CRL $28.0 \mathrm{~cm}$. Primordial and the first primary follicles are detected in the region near the medulla. Staining $\mathrm{HE}, \mathrm{sb}=50 \mu \mathrm{m}$. $\mathbf{K}$ Longitudinal section through the ovary of fetus with CRL $44.8 \mathrm{~cm}$. Mostly germ cell cords are regressed (arrow). More primordial and primary follicles appear towards the periphery of the cortex. Antibody against laminin, $s b=$ $100 \mu \mathrm{m}$. L Detail of the peripheral region of the fetal ovary with CRL $44.8 \mathrm{~cm}$. The remaining germ cell cords (arrow) are always in close contact with the surface epithelium (se). Antibody against laminin, $\mathrm{sb}=80 \mu \mathrm{m}$. M Detail of the cortex of the fetal ovary with CRL 58.0 $\mathrm{cm}$. Differentiated primary follicles are spread in the cortical region. Staining HE, $s b=50 \mu \mathrm{m}$. N Detail of the fetal ovary cortex with CRL $58.0 \mathrm{~cm}$. Secondary follicles are present. Antibody against laminin, $\mathrm{sb}=50 \mu \mathrm{m}$. O Overview of the cortex of fetus with CRL $90.0 \mathrm{~cm}$. The cortex contains all follicles stages. Many primordial and primary follicles are located directly under the surface epithelium (arrow). Tertiary follicles ( $\mathrm{tf}$ ) are prominent in the cortex. Staining HE, $\mathrm{sb}=150 \mu \mathrm{m}$. P Detail of a tertiary follicle. Note the multilayered granulosa cell layer (gc) and also the adapting theca cell layers (arrow). Ovary of fetus with CRL $90.0 \mathrm{~cm}$. Staining HE, $\mathrm{sb}=100 \mu \mathrm{m}$. $\mathbf{Q}$ Detail of the region directly under the ovary surface epithelium from a fetus of CRL $94.0 \mathrm{~cm}$. Sporadic germ cell cords which are connected with the surface epithelium can be observed. Antibody against laminin, $\mathrm{sb}=50 \mu \mathrm{m}$.
PGCs are found. The PGCs migrate through the surface epithelium and stay mainly in the cortical region of the ovary (fig. 1C). PGCs in this region are round and sometimes oval-shaped cells with a large nucleus and 1-3 centrally located prominent nucleoli. The basal lamina beneath the surface epithelium is distinct but appears discontinuous. Oogonia are frequently found near or under the broken basal lamina. They are somewhat larger than PGCs with a more spherical shape and a rounded nucleus. The cytoplasm of PGCs and oogonia is less eosinophilic than that of other cell types. Cells of mesonephric tubules and of the glomerular capsules are found infiltrating the medullar region. The medulla occasionally contains single PGCs. 


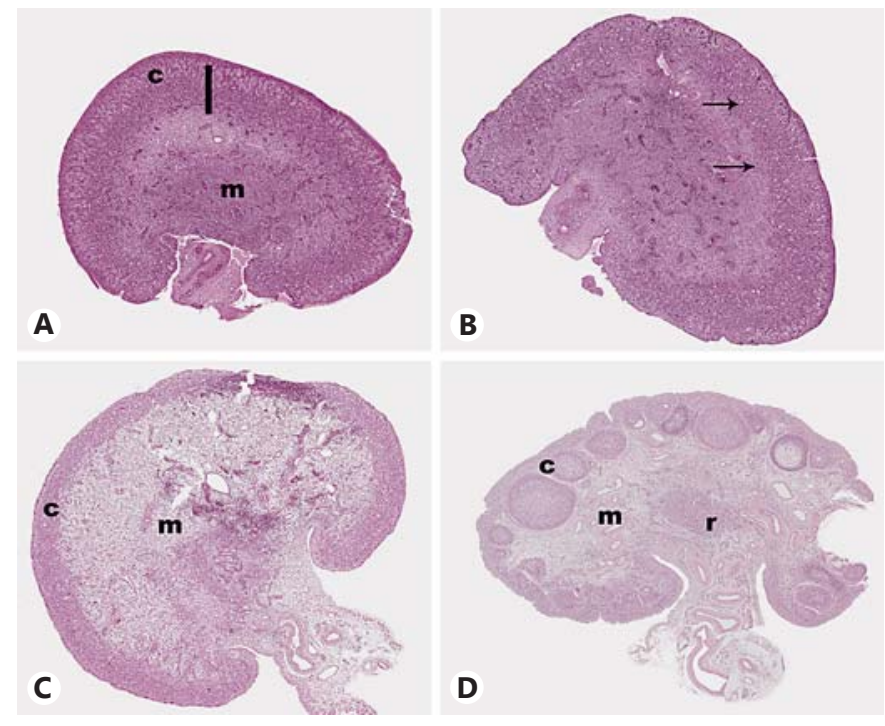

Fig. 2. A-D show the successive developing stages of the bovine fetal ovary between the CRL 21.0-94.0 cm (days 95-285). A Note the broad cortical region (line) which consists of germ cell nests and germ cell cords. Ovaries of CRLs between 21.0-34.0 cm (days 95-150). $c=$ Cortex; $m=$ medulla. $\mathbf{B}$ The germ cell cords are reduced, and near the cortical-medulla region various follicle stages (arrows) can be observed. Ovaries of CRLs between 44, 8 and 58, $0 \mathrm{~cm}$ (days 160-196). C The cortex is more narrowed in contrast to the earlier developing stages. In contrast, the medulla region is broad and contains a lot of vessels. Ovaries of CRLs between 66.0 and $74.0 \mathrm{~cm}$ (days $200-230 \mathrm{~cm}$ ). D Note the tertiary follicles lying in the cortex and the rete ovarii (r) within the medulla. Ovaries of CRLs between 90.0 and $94.0 \mathrm{~cm}$ (days 240-285).

Ovaries Obtained from Bovine Fetuses with a CRL of 5.1-7.4 cm CRL (55-62 days p.c.)

Gonads have enlarged and become round to oval. Fetal ovaries are now distinctly separated from the degenerating mesonephric tissue. The number of PGCs and oogonia has increased. They are frequently located directly in and under the proliferated surface epithelium, arranged in groups or clusters. Germ cell groups are separated from the ovarian mesenchyme by a laminin-positive basal lamina, which is continuous with the surface epithelium in several regions. Groups of PGCs and oogonia are surrounded by dark, elongated somatic cells, which appear morphologically very similar to the epithelial cells. The ovary still does not possess a distinct tunica albuginea. The irregular shaped germ cell groups are in open connection with the ovarian surface epithelium. At this development stage, the surface epithelium consists mostly of 4-7 cell layers, but immunostaining with antibodies against laminin demonstrate that the basal lamina under- neath this multilayered epithelium is still incomplete. The enlarged ovary medulla consists of irregularly formed mesenchymal cells, lymph vessels and large blood vessels also containing some PGCs. Single germ cells in the medulla are not arranged in groups and are equally not in close contact with the small, dark somatic cells.

\section{Ovaries Obtained from Bovine Fetuses with a CRL}

of $11.0-15.8 \mathrm{~cm}$ (76-93 days p.c.)

The ovarian surface epithelium consists of a single- or multilayered epithelium with high prismatic cells, located on an incomplete, distinct, laminin-positive basal lamina, which is pronounced in some regions. The outer surface epithelium cells have often lost their polarity and appear irregularly shaped. Epithelial cells near to the basal lamina preserve their columnar polarized shape. PGCs appear within and beneath the surface epithelium. Generally, the ovarian cortex in this developmental stage consists of closely packed PGCs and oogonia arranged in groups. They are in close contact with dark somatic cells and covered by a laminin-positive basal lamina. Oogonia are larger than PGCs and usually round. Elongation of the cortical located germ cell groups, containing oogonia in close contact with somatic cells, is the first recognizable step in the developing process of germ cell cords near the cortical-medulla area (fig. 2D). Sparsely connective tissue separates the developing germ cell cords. They comprise oogonia frequently showing mitoses and make close contact with dark somatic cells (fig. 1E). These somatic or pregranulosa cells are mostly longitudinally arranged to the groups of oogonia (fig. 1F). The stroma between the germ cell cords contains many capillaries. The stromal cells are long and fusiform with oval nuclei, containing mostly 2 nucleoli. They can be discerned morphologically from pregranulosa cells. They are characterized by a light eosinophilic cytoplasm. Pregranulosa cells, on the other hand, are very similar to surface epithelial cells (elongated, columnar formed, elongated central nucleus, dark eosinophilic cytoplasm) and always show direct contact to PCGs and oogonia. Oocytes entering meiosis are located in the cortical area adjacent to the medulla. The oocytes are bigger and display a lighter and inhomogenously stained cytoplasm. Apparently the basal lamina at the end of the germ cell cords separate single or groups of oocytes which are surrounded by pregranulosa cells. Subsequently these complexes are separated by a prominent basal lamina (fig. 1G). Finally, each primordial follicle is completely enclosed by a continuous basal lamina. Primordial follicles detached from the germ cell cords contain mostly 1 oocyte surrounded by a single layer of dark, flat- 
tened pregranulosa cells. In the majority of cases, many blood vessels are located in its neighborhood. Oocyte nuclei of primordial follicles are usually located in the more peripheral region of the cell. Occasionally, oocytes and pregranulosa cells compose groups, in which the oocytes appear shriveled and the surrounding pregranulosa cells lack a characteristic follicular adjustment around the oocytes. The medulla of these stages can be distinguished in 2 parts: the inner part in which stroma cells and fibers are in close contact and the outer part with more low-density arrangement of stroma.

Ovaries Obtained from Bovine Fetuses with a CRL of 21.0-34.0 cm (95-150 days p.c.) (fig. 2A)

During this developmental period, the ovaries show rapid growth, due to a strong proliferation of germ, epithelial and stroma cells. A distinct separation of cortex and medulla now becomes evident. The cortex is broad, composed of oogonia, oocytes and pregranulosa cells as well as many germ cell cords. The oogonia divide mitotically forming germ cell cords (fig. $2 \mathrm{H}$ ). Continuous connections between surface epithelium, cortical oogonia groups and germ cell cords can often be observed. The strong laminin-positive basal lamina of the surface epithelium continues to surround oogonia groups as well as developing germ cell cords. The wall of the germ cell cords comprises a prominent and continuous lamininpositive basal lamina, upon which pregranulosa cells rest enclosing the centrally located oogonia. No nervous fibers or blood vessels intrude the germ cell cords. The formation of follicles accelerates, which is documented by a rapid increase in the number of new follicles. Formation of numerous primordial follicles continues in the area between cortex and medulla (fig. 1I). Furthermore, primary follicles are formed and are mostly located at the distal end of germ cell cords in the inner cortex area (fig. 1J). The primary follicles consist of oocytes, surrounded by a regularly formed cuboidal epithelium. Primordial and primary follicles are located in groups within the stroma. All follicles possess a distinct basal lamina. The medullar region consists mainly of thin fusiform-shaped stromal cells. Additionally, dispersed oogonia are found in the medulla, usually as single cells or in small groups near to a blood vessel. No basal lamina surrounds these oogonia. They are also not in contact with pregranulosa cells. Development of blood vessels in the medulla has significantly increased and large blood vessels now enter the ovary via the hilus.
Ovaries Obtained from Bovine Fetuses with a CRL of $44.8-58.0 \mathrm{~cm}$ (160-196 days p.c.) (fig. 2B)

The cortex is more distinctly developed compared to earlier stages. The surface epithelium usually consists of a single cell layer, but occasionally, also regions with multiple layers are found. The surface epithelial cells are smaller and their nuclear staining appears darker than during the previous developmental stage. The surface epithelium occasionally forms crypts and projections. The tunica albuginea becomes more distinct, marking the separation between surface epithelial cells and remaining germ cell cords. Located in the peripheral area of the ovarian cortex, most germ cell cords regress (fig. $1 \mathrm{~K}$ ). The strong reduction of germ cell cords is a result of increased follicle formation in the cortex-medulla interface, which now progresses towards the periphery of the cortex. In contrast to earlier stages, the cortex is reduced in width and is divided into 2 regions. The area directly beneath the surface epithelium consists of germ cell cords, whereas near to the cortex-medulla transition zone newly formed follicles are prominent (fig. 1M). Morphological signs for ongoing follicle-building process are the high number of oogonia in mitosis and the proliferation of pregranulosa cells. Many primordial and primary follicles emerge in the medulla vicinity. Single secondary follicles (fig. $1 \mathrm{~N}$ ) can also be detected in the ovarian cortex at a CRL of $58.0 \mathrm{~cm}$. Occasionally, an early tertiary follicle can be observed. The cortex region close to the surface epithelium contains regressing germ cells cords and primordial follicles. Germ cell cords separate clearly from stromal tissue. In these regions, the continuous connections between the basal lamina of the surface epithelium and the basal lamina of germ cell cords are lost (fig. 1L). The medulla is enlarged. Numerous larger blood vessels can be detected in the interface between cortex and medulla. Additionally, groups of lymphocytes can be observed between the follicles. Lymphocytes can also be localized near to atretic follicles with shrunken oocytes, incomplete zona pellucida and irregularly arranged granulosa cells. These atretic follicles usually show an incomplete basal lamina.

Ovaries Obtained from Bovine Fetuses with a CRL of 66.0-74.0 cm (200-230 days p.c.) (fig. 2C)

Ovarian surface epithelium is generally reduced to one layer although isolated multilayered areas occasionally can be detected. Its basal lamina is distinct and continuous. Active proliferation of PGCs within the surface epithelium is reduced and mitosis of oogonia in the cortex is confined to a small area immediately beneath the surface 

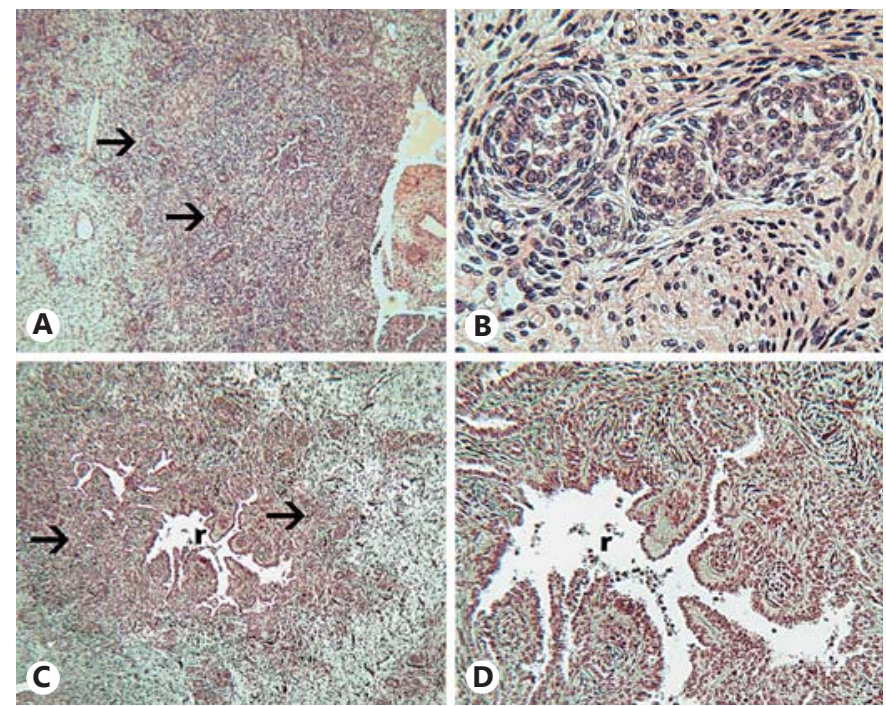

Fig. 3. A In the early developing stages in the medulla, longitudinal and crosswise sliced tubular-like structures are observed (arrows). Ovary of fetus with CRL $11.4 \mathrm{~cm}$, Goldner, $\mathrm{sb}=100 \mu \mathrm{m}$. B In some regions, the tubules begin to anastomose. The epithelium of the tubules is single layered with isoprismatic epithelium cells. The tubules are enclosed in a basal lamina. Ovary of fetus with CRL 11.4 $\mathrm{cm}$, Goldner, $\mathrm{sb}=50 \mu \mathrm{m}$. C In the medulla of CRL $29.9 \mathrm{~cm}$, a welldeveloped rete ovarii ( $\mathrm{r}$ ) can regularly be observed. The rete ovarii is linked with the tubular-like structures in some areas. Partially it can be also detected in the hilus of the developing ovary. Ovary of fetus with CRL $58.0 \mathrm{~cm}$, Goldner, $\mathrm{sb}=100 \mu \mathrm{m}$. D The epithelium of the rete ovarii is single layered with an isoprismatic to high prismatic epithelium. Ciliated cells cannot be found in the epithelium. Ovary of fetus with CRL $58.0 \mathrm{~cm}$, Goldner, $\mathrm{sb}=80 \mu \mathrm{m}$.

epithelium. The tunica albuginea is mostly well developed. It is composed of many fibroblasts and interweaving collagen fibers. Only few germ cell cords are in open connection with the surface epithelium. In these regions, no tunica albuginea has been formed, and the multilayered surface epithelium is located on a discontinuous basal lamina. Oocytes in close contact with pregranulosa cells are found at the distal ends of the germ cell cords close to the medulla. Many primordial and primary follicles are located in the cortex periphery, whereas the growing follicles are restricted to the inner part of the cortex. A laminin-positive basal lamina develops around these germ/somatic cell complexes, giving rise to segregated primordial follicles. Primordial, primary and late secondary follicles are located in the periphery of the cortex region. Secondary follicles show continuous growth and are eventually transformed to early antral follicles with surrounding stromal cells. They form an early theca layer. Atretic secondary and tertiary follicles can now occasionally be observed.

Ovaries Obtained from Bovine Fetuses with a CRL of 90.0-94.0 cm (240-285 days) (fig. 2D)

The cortex is well developed, and a single layer of columnar to cubical epithelial cells covers the fetal ovary surface. Occasionally, a few scattered PGCs can be detected beneath the surface epithelium. The laminin-positive basal lamina is continuous and thicker than in previous developmental stages. Sporadically, small germ cell cords, connected to the surface epithelium, can still be seen. They continue to form primordial follicles at their distal ends (fig. 1Q). The medulla is clearly separated from the cortex and consists of stroma cells as well as large and small blood vessels. All follicle stages from primordial to antral occur in the cortex (fig. 2O). A multilayered columnar granulosa cell layer (fig. 2P) surrounds early tertiary and antral follicle oocytes. The theca layer comprises 3-5 layers of small stromal cells. The theca layer in the enlarged antral follicles can be divided into 2 parts. The inner part, the theca interna, consists of thin circular arranged stroma cells, whereas in the outer part, the theca externa, these stroma cells show a more loose arrangement. Furthermore, all follicles are encircled by a strong laminin-positive basal lamina. Occasionally, atretic tertiary follicles are found within a thin theca cell layer. Granulosa cells of these follicles were irregularly shaped showing large intercellular spaces. Vascularization is significantly increased in the cortex as well as in the medulla.

\section{Intra-Ovarian Rete and Tubular-Like Structures in} the Medulla of the Developing Ovary

From CRL of $11.4 \mathrm{~cm}$ onwards, tubular-like structures can be observed in the medulla (fig. 3A). The tubular epithelium is irregularly shaped and varies between single and multilayered (fig. 3B). The tubular-like structures are enclosed by a strong laminin-positive basal lamina. They are mostly located in the medulla or in the cortex at the end of the germ cell cords. No connection between germ cell cords and the tubular-like structures are observed. An intra-ovarian rete in the bovine fetal ovary is regularly detected from a CRL of $29.9 \mathrm{~cm}$ onwards (fig. 3C). The rete cords consist of a cuboidal to columnar strand of irregular epithelial cells (fig. 3D) and the rete ovarii size increases during fetal development. 
Fig. 4. Overview of the staining pattern of $S 100$ protein (A-D), the proliferation marker Ki67 (E, F) and apoptosis terminal transferasemediated nick-end labeling method $(\mathbf{G}, \mathbf{H})$ in the fetal ovary. A S100 protein is expressed in germ cells, which are located in the surface epithelium or in the stroma beneath the surface epithelium from CRL $11.4 \mathrm{~cm}$ onwards. Antibody against S100 protein, $\mathrm{sb}=50$ $\mu \mathrm{m}$. B In the developing ovary from CRL $21.0 \mathrm{~cm}$ onwards, the nucleus and cytoplasm of all healthy follicle stages are positive for the antibody against S100. In the granulosa cells, only a weak punctual expression of the S100 protein is detected. Antibody against S100 protein, $\mathrm{sb}=80 \mu \mathrm{m}$. C In the ovary of fetus with CRL $94.0 \mathrm{~cm}$, the oocytes of different follicle stages are positive. In oocytes of tertiary follicles (arrow), the immunostaining intensity of S100 increases in contrast to the early follicle stages. Atretic follicle (thick arrow). Antibody against $\mathrm{S} 100$ protein, $\mathrm{sb}=100 \mu \mathrm{m}$. D The oocytes of atretic follicles show no reaction for the antibody against $\mathrm{S} 100$ protein (thin arrow). Between the granulosa cells of the atretic follicles, many S100 positive blood vessels are detected. Note the S100 protein positive oocytes of primordial and primary follicles (thick arrow). Antibody against $\mathrm{S} 100$ protein, $\mathrm{sb}=80 \mu \mathrm{m}$. E In the ovary of fetus with CRL $94.0 \mathrm{~cm}$ in the healthy tertiary follicle, many Ki67-positive granulosa cells are detected (arrow). The atretic follicle directly beneath shows no expression for the antibody against Ki67 in the granulosa cell layers. Further in the stroma cells, positive reactions for the antibody against KI67 are observed. Sb $=100 \mu \mathrm{m} . \mathbf{F}$ In the ovary of CRL 90.0, the intact tertiary follicles contain Ki67 positive granulosa cells (arrows). In contrast, atretic follicles show no reaction for the antibody against KI67 in the granulosa cell layers (thick arrow). $\mathrm{Sb}=100 \mu \mathrm{m}$. G In the ovary of fetus with CRL $94.0 \mathrm{~cm}$, the granulosa cells of the atretic follicles show apoptotic details (arrow). In contrast, in the overlying intact follicles no apoptotic cells are located. $\mathrm{Sb}=100 \mu \mathrm{m}$. $\mathbf{H}$ Apoptotic details in the granulosa cells of tertiary follicle. Ovary of fetus with CRL $94.0 \mathrm{~cm}, \mathrm{sb}=80 \mu \mathrm{m}$. In conclusion, the oocytes of the intact tertiary follicle express the S100 protein $(\mathbf{C})$ and granulosa cells show a positive reaction for the antibody against Ki67 protein (F). In contrast, granulosa cells of the subjacent atretic follicle show no reaction for the antibody against Ki67 (G) and atretic follicles oocytes express no S100 protein (D).
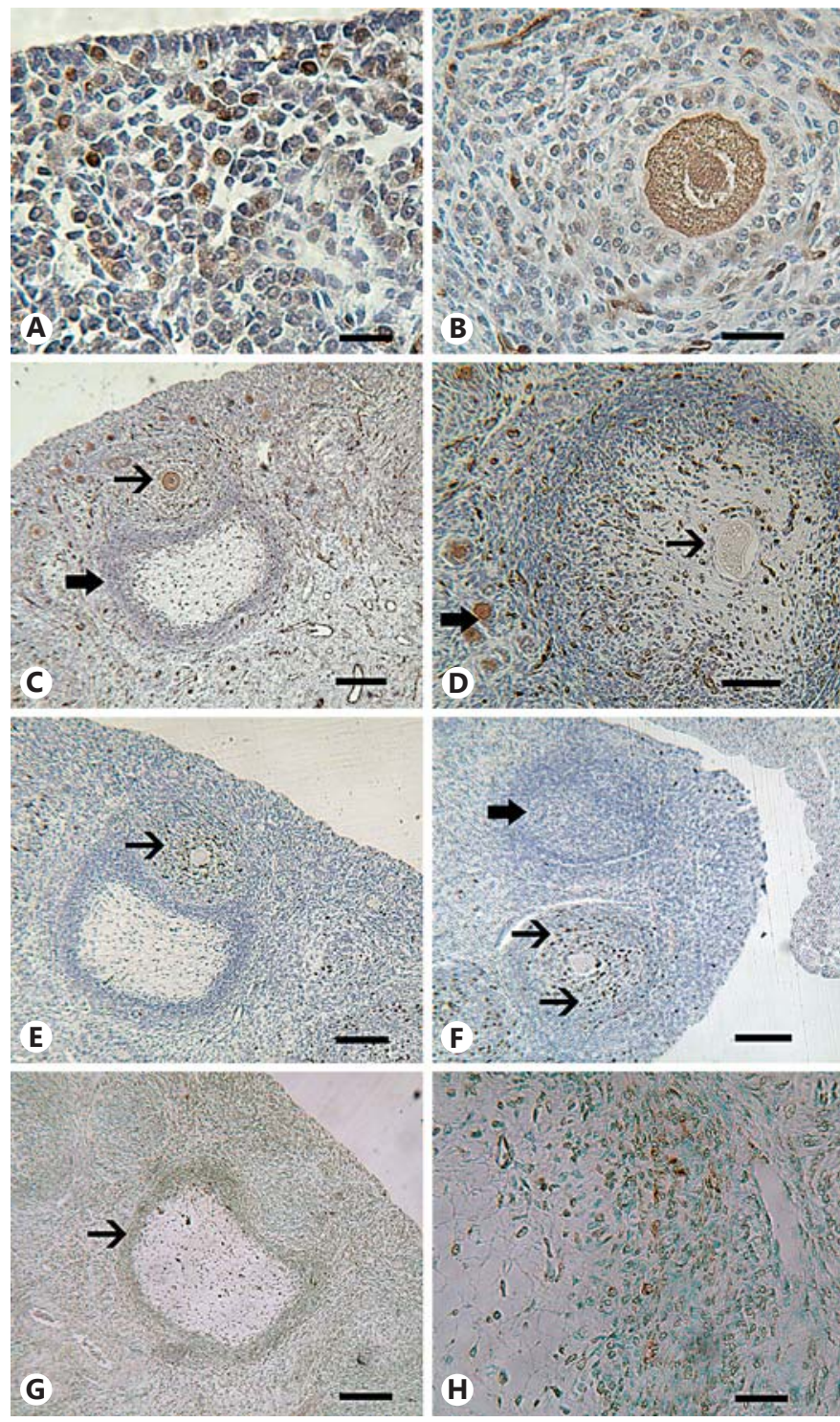

\section{Distribution of S100 Protein and Ki67 Expression}

Generally, no S100 immunostaining is found in the stromal cells of the fetal ovary medulla; however, rete ovarii epithelial cells and tubular-like structures in the hilus, as well as in the developing medulla, show a positive staining for the S100 protein. The stromal septa and tunica albuginea of the later stages show no positive staining with the S100 antibody. A distinctly positive immunostaining is always detected in the endothelium of blood vessels. Weak positive S100 staining is observed in the PGCs/oogonia groups and germ cell cords from a CRL of $11.4 \mathrm{~cm}$ onwards, increasing in later stages (fig. $4 \mathrm{~A})$. Oocytes in ovaries from fetuses with CRL of $21.0 \mathrm{~cm}$ are clearly S100 positive. The immunostaining for S100 in oocytes increases parallel to the oocytes and follicles growth during their development (fig. 4B, C). No positive reaction for S100 protein is found in atretic oocytes and in the pregranulosa and granulosa cells of atretic follicles. Numerous strong positive blood vessels can be observed between the granulosa cells of atretic follicles (fig. 4D). Nuclei, as well as nucleoplasm, show a strong expression for the S100 protein in tertiary follicles oocytes (table 3).

Cell proliferation is investigated using an antibody against Ki67. A positive immunostaining is found in a number of PGCs, oogonia as well as also stroma cells during the early stages of fetal ovarian development. Numer- 
Table 3. Staining pattern of the antibody against $\mathrm{S} 100$

\begin{tabular}{ll}
\hline & Immunostaining of the antibody against \\
& S100 \\
\hline Surface epithelium & - \\
Stroma & - \\
Blood vessels & ++ \\
Stroma medulla & - \\
Rete ovary & + \\
Tubular structures & + \\
PGCs/oogonia & $+/++$ \\
Oocytes & + to +++ \\
Atretic oocytes & - \\
Pregranulosa cells & $-/$ single cells + \\
Granulosa cell & $-/$ single cells + \\
\hline \multicolumn{1}{c}{$=$ Negative; $+=$ weak positive; $++=$ distinct positive; +++} \\
strong positive.
\end{tabular}

ous mitoses are found from a CRL of $0.9-7.4 \mathrm{~cm}$ in all parts of the developing female gonads. In fetuses with a CRL of 7.4-58.0 cm, many more Ki67-positive cells (mostly PGCs) are found within the multilayered surface epithelium and directly under the epithelium (PGCs and oogonia) than during later development stages. Ki67positive oogonia can also be observed in the germ cell cords - mainly in the area near to the surface epithelium. The number of Ki67 positive nuclei increases in the medulla stromal cells as well as in the proliferating germ cells from a CRL of $29.0 \mathrm{~cm}$ onwards. A strong increase in number of mitoses is detected in the surface epithelium of fetal ovaries with a CRL of $13.0-58.0 \mathrm{~cm}$. From a CRL of $66.0 \mathrm{~cm}$ onwards, the number of mitotic figures in the surface epithelium appears distinctly reduced. The oocytes involved in folliculogenesis from a CRL of $21.0 \mathrm{~cm}$ onwards do not express Ki67 protein. Only a few Ki67positive cells can be perceived in the follicle cells. The highest number of Ki67-positive cells in the medulla is seen at CRL $29.0-52.0 \mathrm{~cm}$. Only few stromal cells in the cortex or granulosa cells are Ki67 positive in these stages. A marked increase in number of Ki67-positive granulosa cells is observed from CRL $58.0 \mathrm{~cm}$ onwards. They are usually confined to granulosa cells of healthy tertiary follicles in later stages (fig. 4E). No KI67 immunostaining can be detected in atretic follicles (fig. 4F). Figure 5 gives an overview of the Ki67-positive cells distribution pattern in the surface epithelium and the underlying region in different developmental groups.

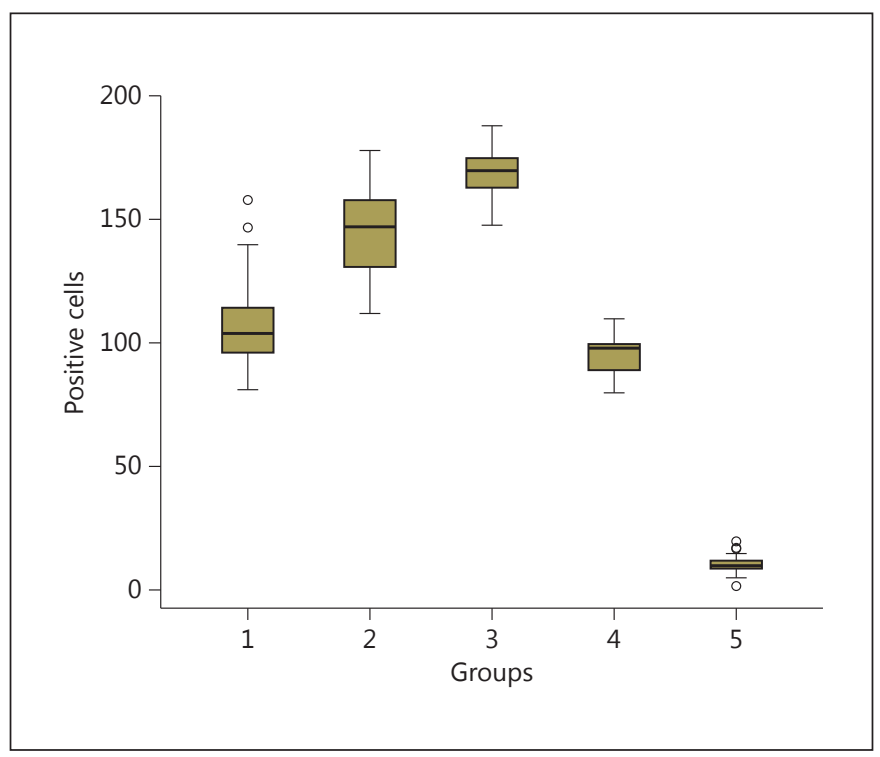

Fig. 5. Distribution of Ki67-positive cells in the surface epithelium and the underlying region in different development groups. Ki67positive cells in the multilayered surface epithelium and directly under the epithelium increase up to CRL $58.0 \mathrm{~cm}$, whereas in later stages, the number of positive cells decreases rapidly. Group 1: $11.0-15.8 \mathrm{~cm}$, group 2: $21.0-34.0 \mathrm{~cm}$, group $3: 44.0-58.0 \mathrm{~cm}$, group 4: $66.7-74.0 \mathrm{~cm}$, and group 5: $90.0-94.0 \mathrm{~cm} . \mathrm{p}<0.05$.

\section{Apoptosis in the Developing Bovine Ovary}

In the surface epithelium, germ cells, stromal cortex cells, and medulla cells of all investigated fetal ovaries, apoptosis can be observed. Between CRL 21.0-46.0 cm the number of apoptotic cells (mostly PGCs and oogonia in the germ cell cords) significantly increases. Apoptotic cells increase in number from a CRL of $46.0 \mathrm{~cm}$ onwards in the surface epithelium. From a CRL $72.0 \mathrm{~cm}$ onwards, apoptosis is confined to granulosa cells of atretic follicles (fig. $4 \mathrm{G}, \mathrm{H}$ ).

\section{Discussion}

As in other species, the appearance of the genital ridge is considered as the first event of bovine gonadal development. According to Wrobel and Suss [1998], the presumptive gonadal region of bovine fetuses first appears at a CRL of $0.9 \mathrm{~cm}$ (days 27-31) as a marked thickening of the mesonephros coelomic epithelium on its ventromedial side, consisting of irregularly arranged columnar, epithelial-like cells with dark cytoplasm and prominent nuclei. Additionally, PGCs can be easily distinguished as 
large round-shaped cells with a lighter eosinophilic cytoplasm compared to the other cell types of the genital ridge. Earlier studies describe that the gonad formation starts with migration and penetration of germ cells into the gonadal region, which is situated on the ventral side of the mesonephros [Brambell, 1927; Witschi, 1948]. Precursor cells of the later sperm or oocytes in mammalians are PGCs, a transient population of germ line stem cells which can be found during embryonic development [McLaren, 2003]. During the indifferent stage of gonadal development, PGCs migrate from the yolk sac via the hindgut wall and dorsal mesentery into the genital ridge [Witschi, 1948]. First PGCs reach the human genital ridge during the 6th week of gestation, whereas in mouse PGCs arrive in the genital ridge at embryonic days 11-12. During migration, the PGCs divide mitotically [Witschi, 1948; Anderson et al., 1999; Wylie, 1999; Stoop et al., 2005]. In bovine fetuses, PGC migration normally takes place between day 30 and 64 of gestation [Rüsse and Sinowatz, 1998]. They continue to proliferate by mitosis reaching an estimated peak number of 2.1 million [Erickson, 1966; Aerts and Bols, 2010]. From CRL 1.8-2.9 cm, genital ridge epithelium and underlying mesenchymal cells have proliferated. The undifferentiated gonad becomes enlarged and elongated, expanding continuously. The genital ridge is now called genital fold [Rüsse and Sinowatz, 1998]. The PGCs number in the investigated bovine fetuses has increased. There are numerous Ki67positive PGCs in the indifferent bovine gonad. Our results are consistent with those reported by Wrobel and Suss [1998], describing a large number of PGCs in the developing bovine genital region up to day 27. Furthermore, Wrobel and Suss [1998] specify the period of the undifferentiated gonad between days 32 and 39 in bovine fetuses. In their investigations, they observed that the indifferent spindle-shaped gonad, which is located on the ventromedial side of the bovine mesonephros, expands quickly [Wrobel and Suss, 1998]. In rat, a thickened area can be identified as genital ridge at the stage of 16 somites [Torrey, 1947]. In rat embryos of 35 somites (12 days), many mitotic figures of all kinds of cells are seen in the mid-level of the gonadal blastema. It is generally accepted that the presence of PGCs is an important factor for the induction of further gonadal development [Leung and Adashi, 2003]. From a CRL of $2.8 \mathrm{~cm}$ onwards, we could distinguish the developing female gonad from the male gonad by the absence of a tunica albuginea. In this study, PCGs have colonized the anlage of the bovine ovary from CRL 2.8-3.6 cm. At this developmental stage, PGCs are frequently found in the surface epithelium. After migra-

Fetal Development of the Bovine Ovary tion through the surface epithelium, they differentiate into Ki67-positive oogonia, which are mainly located in the cortical region of early developing bovine ovary. The oogonia are larger and more eosinophilic than the PGCs. Byskov [1980] describes PGCs reaching the gonadal ridge and continuing their mitotic division for a defined period (the length of which varies between species), now being referred to as oogonia. At a certain moment, oogonia enter the prophase of the first meiotic division where they are put on hold in the diplotene stage [Byskov, 1980].

Another interesting feature of prenatal ovary development in the bovine is the distinct but noncontinuous laminin-positive basal lamina of the genital ridge and the genital folds in the developing female gonad. Similar to our observation, Torrey [1947] finds a discontinuous basal lamina under the surface epithelium of the early rat gonad. We assume that an incomplete basal lamina facilitates the migration of the PGC into the gonadal mesenchyme. In contrast to the anlage of the gonad, the surface epithelium of the remaining mesonephros is separated from the underlying stroma by a well-defined continuous, laminin-positive basal lamina. In agreement with findings of Wrobel and Suss [1998], we also observed that the majority of PGCs and oogonia is in close contact to the vanishing strongly laminin-positive basal lamina and the proliferating genital ridge epithelium. In line with Wrobel and Suss [1998], we also find that during later stages of ovarian development, laminin-positive staining of the basal lamina disappears in areas where PGC immigrate into the ovary stroma. Due to fragmentation of the basal lamina, PGCs and oogonia can protrude into the deeper ovary areas. Subsequently, ovary peripheral stroma shows many Ki67-positive mesenchymal cells. The high number of mitoses may contribute to the active rearrangement of stromal cells around the immigrating PCGs.

An additional important process during fetal bovine ovary development is proliferation of PGCs/oogonia as well as epithelium surface cells, taking place during formation of 'germ cell nests' and 'germ cell cords'. Proliferation of PGCs and oogonia by mitosis occurs mainly in early development stages. In Mongolian sheep, proliferation of oogonia arises during early stages of fetal development (day 37-55 p.c.) [Qi et al., 2008]. Furthermore, Eckery et al. [1996] and Sawyer et al. [2002] report an increase in the oogonia number in sheep up to day 75 of gestation. In the present study, the female gonads of bovine fetuses with a CRL of 5.1-6.1 cm display a broad and dense cortical region, adjacent to the proliferating, multilayered epithelium and a less dense medullar central zone. The 
number of PGCs and oogonia in the dense region in close vicinity to the proliferated surface epithelium increase. PCGs and oogonia are arranged in germ cell nests, interspaced by somatic cells. These results are consistent with findings of Zayed et al. [2007] in mice. These authors observe more or less separated 'egg nests' consisting of 6-8 germ cells in addition to somatic cells in the murine ovary on days $13-14$ p.c. In this study, bovine fetuses with a CRL of $11.4-15.8 \mathrm{~cm}$ show a considerable increase in germ cell nests number of in the broad cortical region containing PGCs, oogonia and somatic cells. Sawyer et al. [2002] describe that in sheep most pregranulosa cells are in close contact with oogonia by the day 38 of gestation. In line with the findings of Sawyer et al. [2002], who describe germ cell nests at day 38 in sheep ovary, the formation of germ cell nests in the bovine ovary starts at a CRL of $11.4 \mathrm{~cm}$ giving rise to germ cell cords. Germ cells entering the prophase of meiosis are initially detected at the end of germ cell cords near to the medulla. The number of bovine oogonia in germ cell nests increases rapidly until a CRL of $34.0 \mathrm{~cm}$, whereas during later stages, up to a CRL of $74.0 \mathrm{~cm}$, the number of oogonia showing mitosis and germ cell nests decreases.

Creation and depletion of germ cell cords is an important event in later developmental stages. The germ cell nests are continuously transformed to germ cell cords in bovine fetal ovaries up to a CRL of $34.0 \mathrm{~cm}$. Epithelial bridges between the proliferated surface epithelium and the germ cell cords are often present. The strong lamininpositive basal lamina of surface epithelium is in continuity with the basal lamina of the germ cell cords. Our results are in agreement with data in fetal sheep, where numerous ovigerous cords are delineated by a basal lamina [Sawyer et al., 2002]. Furthermore, Sawyer et al. [2002] also report that the ovigerous cords of sheep ovary were open to the surface epithelium until day 90. In accordance to the investigation of Burkhart et al. [2010] and Sawyer et al. [2002], this study shows that the germ cell cords in connection with the surface epithelium may play an important role for the recruitment of somatic cells from the surface epithelium. This idea is also consistent with the concomitant high proliferation rate in the multilayered surface epithelium up to a CRL of $58.0 \mathrm{~cm}$ as well as the parallel increase in the number of Ki67-positive oogonia in germ cell cords up to a CRL of $34.0 \mathrm{~cm}$. In contrast, pregranulosa cells forming the wall of germ cell cords near to the medulla show only a small number of KI67positive cells. Most of the BrdU positive cells in sheep ovigerous cords can be attributed to dividing oogonia near the surface epithelium, whereas only a few pregran- ulosa cells of ovigerous cords are stained for BrdU [Sawyer et al., 2002]. The tunica albuginea becomes more evident and marks the separation between surface epithelium and strongly reduced germ cell cords in bovine ovaries from $58.0-74.0 \mathrm{~cm}$. In contrast to earlier stages, the cortex of fetal bovine ovaries is diminished and divided into 2 regions. The area directly under the surface epithelium presents few germ cells nests and germ cells cords, decreasing parallel to the increasing CRL stages of $58.0 \mathrm{~cm}$ onwards. The surface epithelium is always multilayered with high mitotic index in areas with remaining germ cell cords. An additionally important observation is the expression of Ki67 in surface epithelium cells decreasing from $58.0 \mathrm{~cm}$ onwards, as the epithelium is more prone to being single-layered. Furthermore, the number of mitotic oogonia decreases together with the reduction of germ cell cords between CRL of $58.0-74.0 \mathrm{~cm}$. The strong decline in germ cell cords is the result of increasing follicle formation beneath the cortex-medulla border seen from a CRL of $21.0 \mathrm{~cm}$ onwards.

In agreement with the observations in human fetuses of Motta et al. [1997] and Motta and Makabe [1982], in bovine fetus the development of germ cell cords coincides with the proliferation of surface epithelial cells. Further mitotic division of PGCs/oogonia takes place within and beneath the ovarian surface epithelium. Additionally, in line with our results, Motta and Makabe [1982] describe a continuous basal lamina connecting the multilayered epithelium with the developing germ cell cords. They frequently observe that early follicle formation occurs parallel to surface epithelial cell proliferation as well as germ cell cord formation. Moreover, results in bovine ovary show morphology of the surface epithelial cells being very similar to cells building the outer wall of germ cell cords. In contrast, the stromal cells between the germ cell cords are polygonal with a small round to oval nucleus.

In all developing ovaries from a CRL $11.4 \mathrm{~cm}$ onwards, tubular-like structures and channels of an intra-ovarian rete are regularly detected. Burkhart et al. [2010] describe rete tubules from day $110-150$ in the innermost region of the cortex between the ovigerous cords. In this study, also tubular-like structures are often located in the medulla or perpendicular to the germ cell cords. Numerous blood vessels are traced close to the tubular-like structures. In contrast to Burkhart et al. [2010], who mention that rete tubules usually have no basement membrane, the tubular-like structures in fetal bovine ovary possess strong laminin-positive basal lamina. These (tubular-like) structures and the rete tubules show a cubical to columnar, irregularly shaped epithelium. In sheep [Zamboni et al., 
1979] and mice, it is assumed that granulosa cells derive mainly from mesonephric tubules or rete ovarii cells [Byskov et al., 1977]. Additionally, Byskov et al. [1977] and Zamboni et al. [1979] cannot exclude the possibility that surface epithelial cells might also contribute cells for ovigerous cords development as well as for follicle formation. In bovine fetal ovaries, we cannot observe any connection between the rete ovarii tubules or tubular-like structures with germ cell cords involved in follicle formation. Furthermore, comparatively few Ki67-positive cells and mitosis figures can be observed in tubules and rete ovarii in all investigated stages.

Further interesting observation in our study is the low mitotic index of pregranulosa cells within the germ cell cords. As Sawyer et al. [2002] in sheep and Burkhart et al. [2010] in the cattle, who find that ovigerous cords open to surface epithelium until day 90 and day 130, we observed germ cell cords being connected to surface epithelium up to a CRL of $94.0 \mathrm{~cm}$, and therefore, suggest that pregranulosa cells are recruited from the proliferated surface epithelium. The results of this study support the hypothesis that proliferating surface epithelial cells play an important role in the formation of follicular granulosa cells [Gondos, 1975].

Apoptosis is a process of programmed cell death, which plays a major role during the development of many organs, including the ovary [Kerr et al., 1972]. In human, Vaskivuo and Tapanainen [2003] describe apoptosis as an essential mechanisms of ovarian function and development. It is well established that in human the majority of PGCs in the ovary undergoes apoptosis during prenatal life [De Pol et al., 1998]. Smith et al. [1993] describe a loss of $75 \%$ of the PGCs by apoptosis. In this study, we observe apoptosis in all investigated stages of the fetal ovaries affecting germ cells as well as somatic cells. An increase of apoptotic PGCs and oogonia in the germ cell cords is found between the CRL of 21.0 and $46.0 \mathrm{~cm}$. An additional increase of apoptotic cells is detected at a CRL $46.0-72.0 \mathrm{~cm}$. The apoptotic cells are preferentially located under the ovarian surface epithelium cells. Apoptosis is also frequently found in granulosa cells of the primordial follicles situated near to the medulla. Only a few primordial follicle oocytes show apoptosis during the initial stages of primordial follicle formation. In Mongolian sheep, Qi et al. [2008] describe that apoptosis occurs in germ cells between day 37 and 99 with a peak between day 58 and 73. In accordance with our results, they observe that most apoptotic cells are germ cells within ovigerous cords. Other cell types are only rarely affected. Apoptotic germ cell degeneration in the human fetal ovary takes place in 2 waves: an early wave destroying early oogonia and oocytes and a late wave demounting oocytes in the pachytene stage [De Pol et al., 1998]. In line with Zayed et al. [2007], who find apoptosis in mice ovary around $15 / 16 \mathrm{dpc}$, we assume that the strong increase of apoptotic PGCs and oogonia in germ cell cords from CRL 21.0-46.0 and in surface epithelium from CRL 46.0-72.0 $\mathrm{cm}$ is a physiological process after a period of rapid cell proliferation. Furthermore, Zayed et al. [2007] suppose that remaining PGCs which failed to divide mitotically were deleted. Like Qi et al. [2008], we usually find apoptosis in granulosa cells of initial primordial follicle stages. Sporadic apoptosis occurs in primordial follicles oocytes. During later developmental stages from a CRL of $72.0 \mathrm{~cm}$ onwards, apoptotic cells are mainly detected in granulosa cells of atretic follicles. This result is in line with Daikoku et al. [1998] describing the fact that in adults atretic follicles are characterized by presence of apoptotic granulosa cells, whereas apoptosis of oocytes occurs later in development. According to the investigations of Mosimann and Kohler [1990], follicle atresia in primary and secondary bovine follicles is characterized by oocytes shrinkage and disaggregation of granulosa cell layers. The lamininpositive basal lamina breaks down or disappears completely. Atretic changes in antral follicles occur first in granulosa cells and subsequently in oocytes.

A further interesting result of this study is the expression of S100 protein in germ cells and oocytes in addition to a positive immunostaining for S100 in the epithelium of tubular-like structures and the rete ovary. Further, the endothelium of arteries and capillaries are also strongly positive for the S100 protein. In germ cells, a weak S100 immunostaining (in nests and cords) can be observed from a CRL of $11.4 \mathrm{~cm}$ onwards. Weak S100-positive oocytes can be already detected in some primordial follicles at a CRL of $21.0 \mathrm{~cm}$. On the other hand, atretic follicles contain S100-negative shrunken oocytes. The staining intensity of S100 increases parallel to the growth of oocytes during follicle development. Oocytes of healthy secondary and antral follicles are strongly S100 positive from a CRL of $74.0 \mathrm{~cm}$ onwards. Additionally, granulosa cells of these follicles show numerous KI67-positive nuclei. Atretic tertiary follicles possess S100-negative oocytes, their granulosa cells being negative for Ki67. Small S100positive blood vessels penetrate the dispersed granulosa cells. Immunoreactivity for S100 protein was also observed in the ovarian rete as well as in ovarian cysts [Kamiya et al., 1989]. Haimoto et al. [1987] describe S100 expression in the oocytes of primordial follicles and in their follicle epithelium. Mirecka et al. [1994] do not find 
any oocyte S100 staining, neither in growing nor in atretic follicle oocytes. They detect a positive S100 staining in follicular cells with a decrease in reaction intensity parallel with an increase in follicle size. Michetti et al. [1985] on the other hand cannot find S100 expression in any rat ovary cell type. Vanstapel et al. [1986] assume that the contradictory ovary S100 expression results due to species differences or to the use of different antibodies. The authors report that these results of S100 immunostaining can vary, depending whether mono- or polyclonal antibodies of the same nominal specificity are used. The results of our study suggest that positive S100 in combination with positive Ki67 immunostaining in granulosa cell layer can be used as a clear indication for a healthy follicle.

The mechanisms for initial follicle formation found in our investigation support the results of Tanaka et al. [2001] in fetal bovine ovaries. Tanaka et al. [2001] describe primordial, primary and secondary follicles at days 74, 91 and 120. These data agree well with our findings, where primordial, primary and secondary follicles at days 76 and 95 to 150 are observed, respectively. In our study, early antral follicles are first noticed at day 160 , similar to the results of Sawyer et al. [2002]. Contrary to our data, Burkhart et al. [2010] also find antral follicles at day 170, whereas we detected early antral follicles at day 240 . Tanaka et al. [2001] report the appearance of antral follicles at day 233 in bovine fetal ovaries. A somewhat later formation of primordial, primary and secondary follicles (at days 90, 140 and 210) is described in other studies of the bovine fetal ovary [Dominguez et al., 1988; Yang and Fortune, 2008]. In line with Burkhart et al. [2010], we think that differences in the description of important ovarian development steps and fetal folliculogenesis can be due to various follicle classification systems as well as genetic variations in cattle.

\section{Acknowledgement}

The authors thank Ms. Gabriele Russmeier for assistance with immunohistochemical studies.

\section{References}

-Aerts JM, Bols PE: Ovarian follicular dynamics. A review with emphasis on the bovine species. Part II: Antral development, exogenous influence and future prospects. Reprod Domest Anim 45:180-187 (2010).

-Anderson R, Fässler R, Georges-Labouesse E, Hynes RO, Bader BL, et al: Mouse primordial germ cells lacking betal integrins enter the germline but fail to migrate normally to the gonads. Development 126:1655-1664 (1999).

Baumgartner EA: Zur Entwicklung des Genitaltraktes beim Rind. Thesis, Bern (1910).

Brambell FWR: The development and morphology of the gonads of the mouse. I: the morphogenesis of the indifferent gonad and of the ovary. Proc Roy Soc Lond B:391 (1927).

- Burkhart MN, Juengel JL, Smith PR, Heath DA, Perry GA, et al: Morphological development and characterization of aromatase and estrogen receptors alpha and beta in fetal ovaries of cattle from days 110 to 250 . Anim Reprod Sci 117:43-54 (2010).

Byskov AG: The role of the rete ovarii in meiosis and follicle formation in the cat, mink and ferret. J Reprod Fertil 45:201-209 (1975).

Byskov AG: Sexual differentiation of the mammalian ovary, in Motta PM, Hafez ESE (eds): Biology of the Ovary (Martinus Nijhoff Publishers, The Hague 1980).

Byskov AG: Differentiation of mammalian embryonic gonad. Physiol Rev 66:71-117 (1986).
Byskov AG, Lintern-Moore S: Follicle formation in the immature mouse ovary: the role of the rete ovarii. J Anat 116:207-217 (1973).

Byskov AG, Skakkebaek NE, Stafanger G, Peters $\mathrm{H}$ : Influence of ovarian surface epithelium and rete ovarii on follicle formation. J Anat 123:77-86 (1977).

Clara M: Entwicklungsgeschichte des Menschen, ed 5 (Thieme, Leipzig 1965).

Daikoku E, Ito Y, Otsuki Y: The induction of apoptosis in ovaries and uteri of $b c l$-2-deficient mice. Med Electron Microsc 31:68-76 (1998).

De Pol A, Marzona L, Vaccino F, Negro R, Sena $\mathrm{P}$, Forabosco A: Apoptosis in different stages of humen oogenesis. Anticancer Res 18:34573461 (1998).

Didier E: Recherches sur la morphogenese du canal de müller chez les oiseaux. Wilhelm Roux Arch 172:287-302 (1973).

Dominguez MM, Liptrap RM, Basrur PK: Steroidogenesis in fetal bovine gonads. Can J Vet Res 52:401-406 (1988).

Eckery DC, Tisdall DJ, Heath DA, McNatty KP: Morphology and function of the ovary during fetal and early neonatal life: a comparison between the sheep and brushtail possum (Trichosurus Vulpecula). Anim Rep Sci 42: 551-561 (1996).

Edson MA, Nagaraja AK, Matzuk MM: The mammalian ovary from genesis to revelation. Endocr Rev 30:624-712 (2009).
Erickson BH: Development and radio response of the prenatal bovine ovary. J Reprod Fertil 11: 91-105 (1966a).

Erickson BH: Development and senescence of the postnatal bovine ovary. J Anim Sci 25:800805 (1966b).

Fischel A: Lehrbuch der Entwicklung des Menschen. (Springer Verlag, Wien, Berlin 1929).

Fortune JE: The early stages of follicular development: activation of primordial follicles and growth of preantral follicles. Anim Reprod Sci 78:135-163 (2003)

Fulton N, Martins da Silva SJ, Bayne RA, Anderson RA: Germ cell proliferation and apoptosis in the developing human ovary. J Clin Endocrinol Metab 90:4664-4670 (2005).

Gondos B: Surface epithelium of the developing ovary. Possible correlation with ovarian neoplasia. Am J Pathol 81:303-321 (1975).

Grünwald P: The relation of the growing müllerian duct to the wollfian duct and its importance of the genesis of malformations. Anat Record 81:1-19 (1941).

Haimoto H, Hosoda S, Kato K: Differential distribution of immunoreactive s100-alpha and s100-beta proteins in normal nonnervous human tissues. Lab Invest 57:489-498 (1987).

Hirshfield AN: Heterogeneity of cell populations that contribute to the formation of primordial follicles in rats. Biol Reprod 47:466-472 (1992). 
-Ireland JJ, Ward F, Jimenez-Krassel F, Ireland JL, Smith GW, et al: Follicle numbers are highly repeatable within individual animals but are inversely correlated with FSH concentrations and the proportion of good-quality embryos after ovarian stimulation in cattle. Hum Reprod 22:1687-1695 (2007).

- Jost AJ, Vigier B, Prépin J, Perchellet JP: Studies in the sex differentiation in mammals. Recent Prog Horm Res 29:1-41 (1973).

-Juengel JL, Sawyer HR, Smith PR, Quirke LD, Heath DA, et al: Origins of follicular cells and ontogeny of steroidogenesis in ovine fetal ovaries. Mol Cell Endocrinol 191:1-10 (2002).

- Kamiya S, Tsukushi M, Yamano S, Daigo M: S-100 protein-immunoreactive cells in the bovine ovary. Anat Rec 223:384-386 (1989).

Kenngott R, Sinowatz F: Prenatal development of the bovine ovidcut. Anat Histol Embryol 36: 272-283 (2007).

Kenngott R, Sinowatz F: Expression and distribution of intermediate-filament proteins and laminin during the development of the bovine Müllerian duct. Anat Histol Embryol 37:223230 (2008).

Kenngott R, Vermehren M, Sauer U, Ebach K, Sinowatz F: Cellular expression and localization of estrogen receptor $\alpha$ and progesterone receptor mRNA in the bovine oviduct combining laser-assisted microdissection, quantitative PCR, and in situ hybridization. J Histochem Cytochem 2011:59:312-327.

Leung PCK, Adashi EY: The Ovary, ed 2 (Academic Press, San Diego 2003).

Mauleon P: Oogenesis and folliculogenesis, in Cole H, Cupps PT (eds): Reproduction in Domestic Animals, pp 187-215 (Academic Press, New York 1969).

-McGee EA, Hsu SY, Kaipia A, Hsueh AJ: Cell death and survival during ovarian follicle development. Mol Cell Endocrinol 140:15-18 (1998).

McLaren A: Primordial germ cells in the mouse. Dev Biol 262:1-15 (2003).

Michetti F, Lauriola L, Rende M, Stolfi VM, Battaglia F, Cocchia D: S-100 protein in the testis. An immunochemical and immunohistochemical study. Cell Tissue Res 240:137-142 (1985).

-Mirecka J, Brinck U, Korabiowska M, Schauer A: Localization of S-100 protein in pig ovarian structures. Folia Histochem and Cytobiol 32: 177-180 (1994).

Mosimann W, Kohler T: Zytologie, Histologie und mikroskopische Anatomie der Haussäugetiere. (Paul Parey, Berlin 1990).

Motta PM, Makabe S: Development of the ovarian surface and associated germ cells in the human fetus. A correlated study by scanning and transmission electron microscopy. Cell Tissue Res 226:493-510 (1982).
Motta PM, Nottola SA, Makabe S: Natural history of the female germ cell from its origin to full maturation through prenatal ovarian development. Eur J Obstet Gynecol Reprod Biol 75: 5-10 (1997).

- Mulisch M, Welsch U: Romeis Mikroskopische Technik, ed 18 (Spektrum Akademischer Verlag, Heidelberg 2010).

Noden DM, de Lahunta A: The Embryology of Domestic Animals. Development Mechanisms and Malformations. (Williams and Wilkins, London 1985).

Noll S, Schaub-Kuhnen S: Praxis der Immunhistochemie. (Urban \& Fischer, 2000).

Pelliniemi LJ, Salonius AL: Cytological identification of sex in pig embryos at different gonadal stages. Acta Anat (Basel) 95:558-564 (1976).

Pepling ME, Spradling AC: Female mouse germ cells form synchronously dividing cysts. Development 125:3323-3328 (1998).

Pereda J, Zorn T, Soto-Suazo M: Migration of human and mouse primordial germ cells and colonization of the developing ovary: an ultrastructural and cytochemical study. $\mathrm{Mi}$ crosc Res Tech 69:386-395 (2006).

Picton H, Briggs D, Gosden R: The molecular basis of oocyte growth and development. Mol Cell Endocrinol 145:27-37 (1998).

-Qi A, Zhang Z, Cao G, Zhang Y: Histological study of germ cells development and apoptosis in Mongolian sheep fetal ovaries. Anim Reprod Sci 103:179-186 (2008).

Romeis B, Böck P: 1989: Mikroskopische Technik. Vol. 17. (Urban und Schwarzenegger, München 1989).

Rüsse I: Oogenesis in cattle and sheep. Bibl Anat 24:77-92 (1983)

Rüsse I, Sinowatz F: Lehrbuch der Embryologie der Haustiere (Paul Parey, Berlin/Hamburg 1998).

-Sarraj MA, Drummond AE: Mammalian foetal ovarian development: consequences for health and disease. Reproduction 143:151163 (2012)

-Sawyer HR, Smith P, Heath DA, Juengel JL, Wakefield SJ, McNatty KP: Formation of ovarian follicles during fetal development in sheep. Biol Reprod 66:1134-1150 (2002).

-Smith P, O WS, Hudson NL, Shaw L, Heath DA, et al: Effects of the Booroola gene $(\mathrm{Fecb})$ on body weight, ovarian development and hormone concentrations during fetal life. J Reprod Fertil 98:41-54 (1993).

Smith P, O WS, Corrigan KA, Smith T, Lundy T, et al: Ovarian morphology and endocrine characteristics of female sheep fetuses that are heterozygous or homozygous for the inverdale prolificacy gene (FecX1). Biol Reprod 57: 1183-1192 (1997).
Smitz JE, Cortvrindt RG: The earliest stages of folliculogenesis in vitro. Reproduction 123:185202 (2002).

- Stoop H, Honecker F, Cools M, de Krijger R, Bokemeyer C, Looijenga L H: Differentiation and development of human female germ cells during prenatal gonadogenesis: an immunohistochemical study. Hum Reprod 20:14661476 (2005).

- Tanaka Y, Nakada K, Moriyoshi M, Sawamukai $\mathrm{Y}$ : Appearance and number of follicles and change in the concentration of serum FSH in female bovine fetuses. Reproduction 121: 777-782 (2001).

Torrey TW: The development of the urinogenital system of the albino rat; the urinogenital union. Am J Anat 81:139-157 (1947).

-Vanstapel MJ, Gatter KC, de Wolf-Peeters C, Mason DY, Desmet VD: New sites of human S-100 immunoreactivity detected with monoclonal antibodies. Am J Clin Pathol 85:160168 (1986).

-Vaskivuo TE, Tapanainen JS: Apoptosis in the human ovary. Reprod Biomed Online 6:2435 (2003).

Viebahn C, Lane EB, Ramaekers FC: The mesonephric (Wolffian) and paramesonephric (Müllerian) ducts of golden hamsters express different intermediate-filament proteins during development. Differentiation 34:175-188 (1987)

Wartenberg H, Hilscher B, Hilscher W: Germ cell kinetics during early ovarian differentiation: an analysis of the oogonial cell cycle and the subsequent changes in oocyte development during the onset of meiosis in the rat. Microsc Res Tech 40:377-397 (1998).

Witschi E: Migration of the germ cells of human embryos from the yolk sac to the primitive gonadal fold. Contr Embryol Carnegie Inst 37: 67 (1948).

Wrobel KH, Suss F: Identification and temporospatial distribution of bovine primordial germ cells prior to gonadal sexual differentiation. Anat Embryol (Berl) 197:451-467 (1998).

Wylie C: Germ cells. Cell 96:165-174 (1999).

-Yang MY, Fortune JE: The capacity of primordial follicles in fetal bovine ovaries to initiate growth in vitro develops during mid-gestation and is associated with meiotic arrest of oocytes. Biol Reprod 78:1153-1161 (2008).

Zamboni L, Bezard J, Mauleon P: The role of the mesonephros in the development of the sheep fetal ovary. Ann Biol Anim Biochem Biophys 19:1153-1178 (1979).

Zayed AE, Abd-Elnaeim MM, Abd-Elghaffar S, Hild A, Brehm R, Steger K: Prenatal development of murine gonads with special reference to germ cell differentiation: a morphological and immunohistochemical study. Andrologia 39:93-100 (2007). 